\title{
CURRENT LITERATURE ON ANIMAL LEARNING
}

Citations of current literature are arranged in outline form so that readers may easily find the particular articles in which they are interested. The literature on Animal and Physiological Psychology is divided into two parts, with each part appearing in alternate months. The part covered here consists of Animal Learning. The part to be published next month will consist of citations on Animal Behavior (exclusive of Animal Learning) and Physiological Psychology. The principal headings used are given on the cover along with page references.

\section{CONDITIONING}

COUSINS, L. S., ZAMBLE, E., TAIT, R. W., \& SUBOSKI, M. D. Sensory preconditioning in curarized rats. Journal of Comparative \& Physiological Psychology, 1971, 77, 152-154.

FEENEY, D. M. Evoked responses and background unit activity during appetitive conditioning in dogs. Physiology \& Behavior, 1971, 6, 9-15.

\section{Classical Conditioning}

COLAVITA, F. B., \& SZELIGO, F. Classical conditioning with brain stimulation at one site serving as both CS and US. Physiology \& Behavior, 1971, 6, 41-44.

DAVIS, R. E., \& HOLMES, P. A. ECS-produced retrograde amnesia of conditioned inhibition of respiration in cataleptic goldfish. Physiology \& Behavior, 1971, 7, 11-14.

RUNDLE, G. P., NIEMI, R. R., \& THOMPSON, W. R. Sensory preconditioning effects in young and adult rats. Canadian Journal of Psychology, 1971, 25, 323-335.

TEYLER, T. J. Effects of restraint on heart-rate conditioning in rats as a function of US location. Journal of Comparative \& Physiological Psychology, 1971, 77, 31-37.

THOMAS, E. Role of postural adjustments in conditioning of dogs with electrical stimulation of the motor cortex as the unconditioned stimulus. Journal of Comparative and Physiological Psychology, 1971, 76, 187-198.

WILLIAMS, D. R., \& GAMZEE, E. Classical conditioning of a complex skeletal response. Science, 1971, 171, 923-925.

\section{Nictitating Membrane}

LIU, S. S. Differential conditioning and stimulus generalization of the rabbit's nictitating membrane response. Journal of Comparative \& Physiological Psychology, 1971, 77, 136-142;

PATTERSON, M. M. Inferior collicular CS intensity effect on rabbit nictitating membrane conditioning. Physiology \& Behavior, 1971, 6, 273-278.

SCHNEIDERMAN, N., PEARL, L.,
WILSON, W., METCALF, F., MOORE, J. W., \& SWADLOW, H. A. Stimulus control in rabbits (Oryctolagus cuniculus) as a function of different intensities of intracranial stimulation. Journal of Comparative \& Physiological Psychology, 1971, 76, 175-186.

Conditioned Suppression

BROPHY, J. C., \& TREMBLAY, A. M. One-trial CER as a function of shock intensity. Psychonomic Science, 1971, 25, 13-14.

DAWSON, R. G. Retrograde amnesia and conditioned emotional response i n c u b a tion reexamined. Psychological Bulletin, 1971, 75, 278-285.

DOMJAN, M., \& SIEGEL, S. Conditioned suppression following CS preexposure. Psychonomic Science, 1971, 25, 11-12.

FRIEMAN, J. P., FRIEMAN, J., WRIGHT, W., \& HEGBERG, W. Developmental trends in the acquisition and extinction of conditioned suppression in rats. Developmental Psychology, 1971, $4,425-428$.

JAMES, J. P. Latent inhibition and the preconditioning-conditioning interval. Psychonomic Science, 1971, 24, 97-98.

KARSH, E. B. Effects of conflict on choice behavior of rats. Journal of Comparative \& Physiological Psychology, 1971, 76, 505-514.

KREMER, E. F. Truly random and traditional control procedures in $C E R$ conditioning in the rat. Journal of Comparative \& Physiological Psychology. 1971, 76, 441-448.

MICCO, D. J., \& SCHWARTZ, M. Effects of hippocampal lesions upon the development of Pavlovian internal inhibition in rats. Journal of Comparative \& Physiological Psychology, 1971, 76, 371-377.

QUINSEY, V. L. Conditioned suppression with no CS-US contingency in the rat. Canadian Journal of Psychology, 1971, 25, 69-82.

SNEDDEN, D. S., SPEVACK, A. A., \& THOMPSON, W. R. Conditioned and unconditioned suppression as a function of age in rats. Canadian
Journal of Psychology, 1971, 25, 313-322.

SUITER, R. D., \& LoLORDO, V. M. Blocking of inhibitory Pavlovian conditioning in the conditioned emotional response procedure. Journal of Comparative \& Physiological Psychology, 1971, 76, 137-144.

ULM, R. R., \& CICALA, G. A. Reliable immobility and activity enhancement are produced by a fear CS. Psychonomic Science, 1971, 24, 143-144.

VAN DYNE, G. C. Conditioned suppression with a positive US in the rat. Journal of Comparative \& Physiological Psychology, 1971, 77, 131-135.

\section{Operant Conditioning}

BEECHER, M. D. Operant conditioning in the bat Phyllostomus hastatus. Journal of the Experimental Analysis of Behavior, 1971, 16, 219-223.

DAVIDSON, A. B. Factors affecting keypress responding by rats in the presence of free food. Psychonomic Science, 1971, 24, 135-137.

De LORGE, J. O., \& CLARK, F. C. Observing behavior in squirrel monkeys under a multiple schedule of reinforcement availability. Journal of the Experimental Analysis of Behavior, 1971, 16, 167-175.

HEARST, E., TAUS, S. E., \& KORESKO, M. B. Generalization gradients obtained after continuous reinforcement of an operant response. Psychonomic Science, 1971, 24, 205-206.

ORTIZ, A., GLOVER, A., \& LANG, W. J. The effects of acute and chronic administration of chlorpromazine on the acquisition and extinction of positively reinforced operant responses. Physiology \& Behavior, 1971, 6, 407-412.

SCHICK, K. Operants. Journal of the Experimental Analysis of Behavior, 1971, 15, 413-423.

SCHWARTZ, B., \& WILLIAMS, D. R. Discrete-trials spaced responding in the pigeon: The dependence of efficient performance on the availability of a stimulus for collateral pecking. Journal of the 
Experimental Analysis of Behavior, 1971, 16, 155-160.

URAMOTO, I. Effects upon conditioned response time of contingent photic stimulation in cats. Physiology \& Behavior, 1971, 6, 203-204.

WILTON, R. N., \& CLEMENTS, R. O. The role of information in the emission of observing responses: A test of two hypotheses. Journal of the Experimental Analysis of Behavior, 1971, 16, 161-166.

\section{Conditioned Aversion}

AHLERS, R. H., \& BEST, P. J. Novelty vs temporal contiguity in learned taste aversions. Psychonomic Science, 1971, 25, 34-36.

BRADLEY, R. M., \& MISTRETTA, C. M. Intravascular taste in rats as demonstrated by conditioned aversion to sodium saccharin. Journal of Comparative \& Physiological Psychology, 1971, 75, 186-189.

GROTE, F. W., JR., \& BROWN, R. T. Conditioned taste aversions: Two-stimulus tests are more sensitive than one-stimulus tests. Behavior Research Methods \& Instrumentation, 1971, 3, 311-312.

KALAT, J. W., \& ROZIN, P. Role of interference in taste-aversion learning. Journal of Comparative \& Physiological Psychology, 1971, 77, 53-58.

KRAL, P. A. Effects of scopolamine injection during CS-US interval on conditioning. Psychological Reports, 1971, 28, 690.

NACHMAN, M., LARUE, C., \& LE MAGNEN, J. The role of olfactory and orosensory factors in the alcohol preference of inbred strains of mice. Physiology \& Behavior, 1971, 6, 53-95.

ST. OMER, V. V., \& KRAL, P. A. Electroconvulsive shock impedes the learning of taste aversions: Absence of blood-brain-barrier involvement. Psychonomic Science, $1971,24,251-252$.

SUTKER, L. W. The effect of initial taste preference on subsequent radiation-induced aversive conditioning to saccharin solution. Psychonomic Science, 1971, 25, 1-2.

\section{Imprinting}

CODISH, S. D. Actinomycin D injected into the hippocampus of chicks: Effects upon imprinting. Physiology \& Behavior, 1971, 6, 95-96.

KLOPFER, P. H. Imprinting: Determining its perceptual basis in ducklings. Journal of Comparative \& Physiological Psychology, 1971, $75,378-385$.

PORTER, R. H., \& STETTNER, L. J.
Non-specificity of the following response in Peking ducklings. Perceptual \& Motor Skills, 1971, $33,27-33$.

\section{DISCRIMINATION LEARNING}

ADAMS, D. L., \& ALLEN, J. D. Compound stimulus control by discriminative stimuli associated with high and moderate response rates. Journal of the Experimental Analysis of Behavior, 1971, 16, 201-205.

DALY, H. B. Evidence for frustration during discrimination learning. Journal of Experimental Psychology, 1971, 88, 205-215.

DAVIS, J. M. Testing for inhibitory stimulus control with ssuperimposed on $S+$. Journal of the Experimental Analysis of Behavior, 1971, 15, 365-369.

DOMBER, E. A., FOWLER, H., \& W ISCHNER, G. J. Shock-right facilitation: Correction training with differential SD availability during an enforced delay following an error. Journal of Experimental Psychology, 1971, 89, 329-334.

KENDALL, S. B. Reinforcement by stimuli associated with SPsychological Reports, 1971, 28, 367-374.

REES, R., \& SCHRIER, A. M. S+ and $\mathrm{S}$ - control in Macaca fascicularis using a discriminative switching procedure. Psychonomic Science, $1971,25,9-10$.

RUDOLPH, R. L. Effects of interdimensional discrimination training on stimulus control in monochromatically reared chicks. Psychological Record, 1971, 21, 257-264.

STODDARD, L. T., \& SIDMAN, M. The removal and restoration of stimulus control. Journal of the Experimental Analysis of Behavior, $1971,16,143-154$.

WARD, E. F. Acquisition and extinction of the observing response as a function of stimulus predictive validity. Psychonomic Science, 1971, 24, 139-141.

Successive Discrimination

BACON, W. E. Stimulus control of discriminated behavior in neonatal dogs. Journal of Comparative \& Physiological Psychology, 1971, 76, 424-433.

ELSMORE, T. F. Effects of response effort on discrimination performance. Psychological Record, $1971,21,17-24$.

THOMPSON, D. M. Transition to a steady state of repeated acquisition. Psychonomic Science, 1971, 24, 236-238.

\section{Reversal Learning}

HONIG, W. K., \& AYASSE, S. Line orientation and color as orthogonal stimulus dimensions for the pigeon. Psychological Record, 1971, 21, 229-233.

JOHNSON, J. D., \& GAZZANIGA, M. S. Reversal behavior in split-brain monkeys. Physiology \& Behavior, $1971,6,707-709$.

POWELL, D. A., SCHNEIDERMAN, N., ELSTER, A. J., \& JACOBSON, A. Differential classical conditioning in rabbits (Oryctolagus cuniculus) to tones and changes in illumination. Journal of Comparative \& Physiological Psychology, 1971, 76, 267-274.

RUMBAUGH, D. M. Evidence of qualitative differences in learning processes among primates. Journal of Comparative \& Physiological Psychology, 1971, 76, 250-255.

WOODWARD, W. T., SCHOEL, W. M. \& BITTERMAN, M. E. Reversal learning with singly presented stimuli in pigeons and goldfish. Journal of Comparative \& Physiological Psychology, 1971, 76, 460-467.

\section{Multiple Discrimination}

PLATT, J. J., REISER, D. L., \& MERKNER, J. Response to stimulus change and related temporal parameters in rabbits and guinea pigs. Journal of Genetic Psychology, 1971, 118, 173-178.

WALLER, T. G. The effect of consistency of reward on compound-cue discrimination learning. Psychonomic Science, 1971, 24, 230-232.

WEISS, S. J. Discrimination training and stimulus compounding: Consideration of non-reinforcement and response differentiation consequences of $S^{\Delta^{1}}$. Journal of the Experimental Analysis of Behavior, 1971, 15, 387-402.

Z I M M ER M A N N, R. R . \& HOCHBERG, J. The facilitation of picture discrimination after object discrimination learning in the neonatal monkey and probably vice versa. Psychonomic Science, 1971, 24, 239-241.

\section{Matching to Sample}

CAMPEAU, E., ADEY, W. R., DURHAM, R. M., TOLLIVER, J. D., JR., RINGLER, R., \& KA N N R, R. M. E E G discriminators of delayed matching to sample performance in Macaca nemestrina. Physiology \& Behavior, $1971,6,413-418$.

D'AMATO, M. R., \& O'NEILL, W. Effect of delay-interval illumination on matching behavior in the capuchin monkey. Journal of the Experimental Analysis of Behavior, 1971, 15, 327-333.

MACKAY, H. A., \& BROWN, S. M. Teaching serial position sequences to monkeys with a delayed 
matching-to-sample procedure. Journal of the Experimental Analysis of Behavior, 1971, 15, 335-345.

MELLO, N. K. Alcohol effects on delayed matching to sample performance by rhesus monkey. Physiology \& Behavior, 1971, 7, 77-101.

WILSON, M. Shifts in categorization and identifiability of visual stimuli by rhesus monkeys. Perception \& Psychophysics, 1971, 10, 271-272.

Stimulus Generalization

DOBSON, R., VERHAVE, T., \& HEGGE, F. W. Generalization of indicator needle position in the pigeon. Psychological Record, 1971, 21, 251-256.

ERNST, A. J., ENGBERG, L., \& THOMAS, D. R. On the form of stimulus generalization curves for visual intensity. Journal of the Experimental Analysis of Behavior, 1971, 16, 177-180.

HEARST, E. Contrast and stimulus generalization following prolonged discrimination training. Journal of the Experimental Analysis of Behavior, $1971,15,355-363$.

LIU, S. S. Differential conditioning and stimulus generalization of the rabbit's nictitating membrane response. Journal of Comparative \& Physiological Psychology, 1971, 77, 136-142.

RILEY, D. A., \& LEUIN, T. C. Stimulus-generalization gradients in chickens reared in monochromatic light and tested with a single wavelength value. Journal of Comparative \& Physiological Psychology, 1971, 75, 399-402.

SIEGEL, R. K. Apparent movement and real movement detection in the pigeon: Stimulus generalization. Journal of the Experimental Analysis of Behavior, 1971, 16, 189-192.

SMITH, B. L. Irrelevant stimuli and response rate for a pigeon. Psychonomic Science, 1971, 24, 103-104.

YAGER, D., \& DUNCAN, I.-A. Signal-detection analysis of luminance generalization in goldfish using latency as a graded response measure. Perception \& Psychophysics, 1971, 9, 353-355.

Simple Discrimination Learning

BEECHER, M. D., \& HARRISON, J. M. Rapid acquisition of an auditory localization discrimination by rats. Journal of the Experimental Analysis of Behavior, 1971, 16, 193-199.

BIEDERMAN, G. B. Stimulus control in partially and continuously reinforced simultaneous discrimination. Psychonomic
Monograph Supplements, 1971 4(7, Whole No. 55).

BURESOVÁ, O., \& BUREŚ, J. The effect of prolonged cortical spreading depression on consolidation of visual engrams in rats. Psychopharmacologia (Berlin), 1971, 20, 57-65.

COGAN, D., INMAM, S., \& GAMBREL, M. Discrimination in parakeets (Melopsittacus undulatus) as a function of age. The Psychological Record, 1971, 21, 117-120.

DAVIS, S. F., GILBERT, R. F., \& SEAVER, W. E., III. Stimulus onset and its effect on S+ and Sperformance in differential conditioning. Psychonomic Science, 1971, 25, 29-31.

GLENDENNING, R. L., HOWARD, R. L., \& MEYER, D. R. Stimulus displays which yield rapid learning of two-choice discrimination problems by rats. Behavior Research Methods \& Instrumentation, 1971, 3, 313-315.

HALL, T. L., \& THOMPSON, R. W. Interhemispheric transfer as a function of light intensity discrimination difficulty. Journal of Comparative \& Physiological Psychology, 1971, 77, 166-170.

LUND, J. S., \& HAMILTON, C. R. Visual discrimination of movement: Midbrain or forebrain? Science, $1971,170,1428-1430$.

HARRISON, J. M., DOWNEY, P. SEGAL, M., \& HOWE, M. Control of responding by location of auditory stimuli: Rapid acquisition in monkey and rat. Journal of the Experimental Analysis of Behavior, 1971, 15, 379-386.

LEE-TENG, E., \& BUTLER, S. R. Temperature reinforcement for visual discrimination training in baby chicks. Behavior Research Methods \& Instrumentation, 1971, 3, 247-249.

MANNING, F. J., GROSS, C. G., \& COWEY, A. Partial reinforcement: Effects on visual learning after foveal prestriate and inferotemporal lesions. Physiology \& Behavior, 1971, 6, 61-64.

SACKETT, G. P., TRIPP, R., MILBRATH, C., GLUCK, J., \& PICK, H. A method for studying visually guided perception and learning in newborn macaques. Behavior Research Methods \& Instrumentation, $1971,3,233-236$.

STRATTON, L. O. Effects of dark preference on attention to the positive cue in posterior neodecorticated albino rats. Psychonomic Science, 1971, 24, 105-106.

THORNE, B. M., \& O'BRIEN, A. L. The use of olfactory cues in solving a visual discrimination task.
Behavior Research Methods Instrumentation, $1971,3,240$

MAZE AND RUNWAY BEHAVIOR

(See also Reinforcement, Retention)

BLANCHETEAU, M. "Motor hypothesis" in rats in relation to the cue value and reward value of home cage proximity to the maze. Psychonomic Science, 1971, 24, 151-152.

BOITANO, J. J., PATRISSI, G. A., \& SIMONE, S. A. Effects of magnesium pemoline in dimethylsulfoxide on reversal learning, motor activity, and water intake. Psychological Reports, 1971, 28, 71-79.

DAVIS, S. F., GILBERT, R. F., \& SEAVER, W. E., III. Stimulus onset and its effect on $S+$ and $S-$ performance in differential conditioning. Psychonomic Science, 1971, 25, 29-31.

FRANCHINA, J. J., \& KAISER, P. Acquisition, transfer, and reacquisition of single-alternation responding in the rat. Journal of Comparative \& Physiological Psychology, 1971, 76, 256-261.

HERZ, M. J., \& PEEKE, H. V. S. Caudate nucleus stimulation retroactively impairs complex maze learning in the rat. Science, 1971, $173,80-82$.

MARTIN, R. C., \& DEEMER, B. A multiple-function swimway. Perceptual \& Motor Skills, 1971, 32, 775-780.

MEANS, L. W., LEANDER, J. D., \& ISAACSON, R. L. The effects of hippocampectomy on alternation behavior and response to novelty. Physiology \& Behavior, 1971, 6, 17-22.

PATTEN, R. L. Frustrative facilitation effects of nonzero reward magnitude reduction on goal-box activity and runway locomotion. Journal of Experimental Psychology, 1971, 90, 160-162.

WOLACH, A. H., \& SERES, M. Changes in running speed after incentive shifts. Psychonomic Science, 1971, 23, 238-240.

WONG, P. T. P., \& TRAUPMANN, K. L. Extraacquisitional factors in extinction: The effect of feeding activities of neighboring rats. Psychonomic Science, 1971, 23, 359-360.

\section{AVOIDANCE AND PUNISHMENT \\ (See also Conditioned suppression, Aggression)}

BRADY, J. V., \& ANDERSON, D. E. Preavoidance blood pressure elevations accompanied by heart rate decreases in the dog. Science, $1971,172,595-597$.

WEISS, J. M. Effects of coping behavior in different warning signal 
conditions on stress pathology in rats. Journal of Comparative \& Physiological Psychology, 1971, 77, 1-13.

WEISS, J. M. Effects of coping behavior with and without a feedback signal on stress pathology in rats. Journal of Comparative \& Physiological Psychology, 1971, 77, 22-30.

WEISS, J. M. Effects of punishing the coping response (conflict) on stress pathology in rats. Journal of Comparative \& Physiological Psychology, 1971, 77, 14-21.

\section{Escape Learning}

CICALA, G. A., ULM, R. R., \& DREWS, D. R. The effects of chlorpromazine and d-amphetamine on the acquisition and performance of a conditioned escape response in rats. Psychological Record, 1971, 21, 165-169.

GOTSICK, J. E., OSBORNE, F. H., ALLEN, C. J., HINES, K. M. Factors affecting performance on a shock escape task in rats with septal lesions. Physiology \& Behavior, 1971, 6, 199-201.

MILBY, J. B., JR. Delay of shockescape with and without stimulus change. Psychological Reports, 1971, 29, 315-318.

MISANIN, J. R., ROSE, S. J., \& HIN DERLITER, C. F. Escape behavior in neonatal rats: Methodological and psychometric considerations. Behavior Research Methods \& Instrumentation, 1971, 3, 253-254.

SATINDER, K. P. Genotypedependent effects of d-amphetamine sulphate and caffeine on escape-avoidance behavior of rats. Journal of Comparative \& Physiological Psychology, 1971, 76, 359-364.

WONG, P. T. P. Coerced approach to shock, punishment of competing responses, and resistance to extinction in the rat. Journal of Comparative \& Physiological Psychology, 1971, 76, 275-281.

\section{Avoidance}

ANISMAN, H., \& WALLER, T. G. Effects of methamphetamine and shock duration during inescapable shock exposure on subsequent active and passive avoidance. Journal of Comparative \& Physiological Psychology, 1971, 77, 143-151.

BAUM, M. Effect of alcohol on the resistance-to-extinction of an avoidance response: Replication in mice. Physiology \& Behavior, 1971, 6, 307-309.

BAUM, M. Extinction of an avoidance response in rats via response prevention (flooding): A test for residual fear. Psychological Reports, 1971, 28, 203-208.

BAUM, M., \& HIGGINS, J. A. Extinction of an avoidance response using response prevention (flooding) in the guinea pig. Psychonomic Science, 1971, 25, 3-4.

BAUM, M., \& MYRAN, D. D. Response prevention (flooding) in rats: The effects of restricting exploration during flooding and of massed vs distributed flooding. Canadian Journal of Psychology, $1971,25,138-146$.

BAUM, M., JAFFE, P. G., \& LECLERC, R. The effect of a loud buzzer upon the acquisition and extinction of a simple avoidance response in rats. Canadian Journal of Psychology, 1971, 25, 24-32.

BERSH, P. J., \& KELTZ, J. R. Pavlovian reconditioning and the recovery of avoidance behavior in rats after extinction with response prevention. Journal of Comparative \& Physiological Psychology, 1971, 76, 262-266.

DELINI-STULA, A. Drug-induced suppression of conditioned hyperthermic and conditioned avoidance behavior response in rats. Psychopharmacologia (Berlin), 1971, 20, 153-159.

GUTTMAN, H. N., \& GRONKE, L. Passive transfer of learned dark and step-down avoidance. Psychonomic Science, 1971, 24, 107-108.

HENRIKSSON, B. G., \& JÄRBE, T. Effects of diazepam on conditioned avoidance learning in rats and its transfer to normal state conditions. Psychopharmacologia (Berlin), 1971, 20, 186-190.

JAFFE, P. G., \& BAUM, M. Increased resistance-to-extinction of an avoidance response in rats following the administration of hashish resin. Psychopharmacologia (Berlin), 1971, 20, 97-102.

JAMES, W. T. A methodological study of conditioning and extinction of an avoidance response via social facilitation in dogs. Journal of General Psychology, 1971, 84, 275-279.

MARKS, H. E., REMLEY, N. R., SEAGO, J. D., \& HASTINGS, D. W. Effects of bilateral lesions of the olfactory bulbs of rats on measures of learning and motivation. Physiology \& Behavior, 1971, 7, 1-6.

SEIDEN, L. S., \& MARTIN, T. W., JR. Potentiation of effects of L-dopa on conditioned avoidance behavior by inhibition of extracerebral dopa decarboxylase. Physiology \& Behavior, 1971, 6, 453-458.

SIEGEL, P. S., MELVIN, K. B., \& WAGNER, J. D. Vicious circle behavior in the rat: Measurement problems visited again. Journal of Comparative \& Physiological
Psychology, 1971, 76, 311-315.

\section{Shuttle Avoidance}

ASDOURIAN, D., \& PRESTON, R. J. Cerebellar stimulation as a CS. Physiology \& Behavior, 1971, 6, 235-239.

CARDER, B. Effects of septal stimulation on active avoidance in rats. Physiology \& Behavior, 1971, 6, 503-506.

DYER, R. S. Influences of the visual system upon two-way avoidance learning in the guinea pig. Journal of Comparative \& Physiological Psychology, 1971, 76, 434-440.

GALVANI, P. F. The effects of partial reinforcement on the acquisition and extinction of avoidance behavior in gerbils. Psychonomic Science, 1971, 24, 242-244.

GRANT, M., \& YOUNG, D. The effects of preexposure to a learning apparatus. Behavior Research Methods \& Instrumentation, 1971, 3, 251-252.

ROYCE, J. R., YEUDALL, L. T., \& POLEY, W. Diallel analysis of avoidance conditioning in inbred strains of mice. Journal of Comparative \& Physiological Psychology, 1971, 76, 353-358.

SCHMALTZ, L. W. Deficit in active avoidance learning in rats following penicillin injection into hippocampus. Physiology \& Behavior, 1971, 6, 667-674.

VOITH, K., \& HERR, F. The effect of various antidepressant drugs upon the tetrabenazine-suppressed conditioned avoidance response in rats. Psychopharmacologia (Berlin), 1971, 20, 253-265.

\section{Passive Avoidance}

ALTMAN, J. L., \& WISHART, T. B. Motivated feeding behavior elicited by electrical stimulation of the septum. Physiology \& Behavior, 1971, 6, 105-109.

ANISMAN, H. Passive-avoidance learning in mice following methamphetamine or Nembutal injection during inescapable exposure to shock. Psychological Reports, 1971, 28, 611-614.

BROWN, G. E., HARRELL, E., \& REMLEY, N. R. Passive avoidance in septal and anosmic rats using quinine as the aversive stimulus. Physiology \& Behavior, 1971, 6, 543-546.

LIDSKY, A., \& SLOTNICK, B. M. Effects of posttrial limbic stimulation on retention of a one-trial passive-avoidance response. Journal of Comparative \& Physiological Psychology, 1971, 76, 337-348.

SANDMAN, C. A., KASTIN, A. J., \& SCHALLY, A. V. Behavioral inhibition as modified by 
melanocyte-stimulating hormone (MSH) and light-dark conditions. Physiology \& Behavior, 1971, 6, 45-48.

VARDARIS, R. M., \& SCHWARTZ, K. E. Retrograde amnesia for passive avoidance produced by stimulation of dorsal hippocampus. Physiology \& Behavior, 1971, 6, 131-135.

\section{Discriminated Avoidance}

DILLOW, P. V., \& HURWITZ, H. M. B. Fixed ratio discriminated avoidance: Response contingencies in warning period. Psychological Record, 1971, 21, 107-116.

FLEMING, D. E., WILSON, C. E., \& RHODES, L. E. Topical acetylcholine applications: Electrocortical-behavioral correlations. Physiology \& Behavior, 1971, 6, 739-742.

HOYER, W. J., SHAFER, J. N., MAULDIN, J. E., \& CORBETT, H. T. Discriminated avoidance and escape conditioning with the tadpole (Rana pipiens). Psychonomic Science, 1971, 24, 247-248.

KRIVANEK, J. A. Facilitation of avoidance learning by pentylenetetrazol as a function of task difficulty, deprivation and shock level. Psychopharmacologia (Berlin), 1971, 20, 213-229.

LITNER, J., \& SUBOSKI, M. D. Effects of shock intensity and food deprivation on one-trial discriminated avoidance. Canadian Journal of Psychology, 1971, 25, 185-194.

McGOVERN, L. P., \& HAUDE, R. H. Self-punishment for responding by monkeys during extinction of discriminated avoidance: Effects of previous stimulus change reinforcement. Psychological Reports, 1971, 29, 244-246.

OVERMIER, J. B., BULL, J. A., III, \& TRAPOLD, M. A. Discriminative cue properties of different fears and their role in response selection in dogs. Journal of Comparative \& Physiological Psychology, 1971, 76, 478-482.

RIESS, D. The buzzer as a primary aversive stimulus: III. Unconditioned and conditioned suppression of barpress avoidance. Psychonomic Science, 1971, 24, 212-214.

Free Operant (Sidman) Avoidance

CLAY-FINLEY, A. The effects of length of vacation on free operant avoidance. Psychonomic Science, 1971, 24, 115-117.

DUNN, M. E., FOSTER, W. S.; \& HURWITZ, H. M. B. Effects of cycle length on performance on a temporally defined avoidance schedule. Journal of the Experimental Analysis of Behavior, 1971, 16, 263-268.

GIBBON, J. Scalar timing and semi-Markov chains in free-operant avoidance. Journal of Mathematical Psychology, 1971, 8, 109-138.

HURWITZ, H. M. B., \& ROBERTS, A. E. Conditioned suppression of an avoidance response. Journal of the Experimental Analysis of Behavior, 1971, 16, 275-281.

HURWITZ, H. M. B., \& ROBERTS, A. $\mathrm{E}$. Time-out as a determinant of rate of response and rate of avoidance. Psychonomic Science, 1971, 24, 131-133.

\section{Aversive Stimuli}

BLOOMFIELD, T. M. Facilitation of performance in pigeons by low-intensity electric shocks. Psychonomic Science, 1971, 25, $32-33$.

$\mathrm{BOE}, \mathrm{E}$. E. Recovery from signaled shock as a function of response contingency in rats. Journal of Comparative \& Physiological Psychology, 1971, 77, 122-130.

HOFFMAN, H. S., \& OVERMAN, W., JR. Performance disruption by startle-eliciting acoustic stimuli. Psychonomic Science, 1971, 24, 233-235.

PINEL, J. P. J., MALSBURY, C. W., \& CORCORAN, M. E. The incubation effect produced in rats without footshock. Psychonomic Science, 1971, 24, 109-110.

RIESS, D. The buzzer as a primary aversive stimulus: III. Unconditioned and conditioned suppression of barpress avoidance. Psychonomic Science, 1971, 24, 212-214.

\section{Punishment}

CREER, T. L., \& POWELL, D. A. Effect of repeated shock presentations and different stimulus intensities on shock-induced aggression. Psychonomic Science, $1971,24,133-134$.

DREYER, P., \& RENNER, K. E. Self-punitive behavior-masochism or confusion? Psychological Review, 1971, 78, 333-337.

DUNHAM, P. J. Punishment: Method and theory. Psychological Review, 1971, 78, 58-70.

MacDONALD, L., \& BARON, A. Recovery from punishment as a function of deprivation level. Psychonomic Science, 1971, 24, 119-121.

MARQUIS, H. A., BLACK, M., RICHARDSON, B., TAIT, R. W., WILLIAMS, R., \& SUBOSKI, M. D. Shock intensity and the Kamin effect in one- and two-way avoidance. Canadian Journal of Psychology, 1971, 25, 241-249.
SEGAL, M., HERSHKOWITZ, M., SAMUEL, D., \& BITTERMAN, M. E. Rapid modification of amphibian behavior by punishment. Psychonomic Science, 1971, 24, 249-250.

TELLISH, J. A., \& DUNSTONE, J. J. Punishment of variable ratio maintained behavior. Psychological Record, 1971, 21, 49-52.

\section{REINFORCEMENT}

COLLIER, G., \& HIRSCH, E. Reinforcing properties of spontaneous activity in the rat. Journal of Comparative \& Physiological Psychology, 1971, 77, 155-160.

DAVIDSON, A. B. Factors affecting keypress responding by rats in the presence of free food. Psychonomic Science, 1971, 24, 135-137.

FILION, R. D. L., FOWLER, S. C., \& NOTTERMAN, J. M. Prefeeding, discontinuance of prefeeding, and force-proportional reinforcement. Journal of General Psychology, $1971,85,145-147$.

KENDALL, S. B. Reinforcement by stimuli associated with $\mathrm{S}$-. Psychological Reports, 1971, 28, 367-374.

MEYER, M. E., \& GORDON, S. A. Frequency of light onset on a ctivation and sensory reinforcement in domestic chicks. Psychological Reports, 1971, 28, 769-770.

WIKLER, A., PESCOR, F. T., MILLER, D., \& NORRELL, H. Persistent potency of a secondary (conditioned) reinforcer following withdrawal of morphine from physically dependent rats. Psychopharmacologia (Berlin), 1971, 20, 103-117.

\section{Schedules of Reinforcement}

de LORGE, J, O., \& CLARK, F. C. Observing behavior in squirrel monkeys under a multiple schedule of reinforcement a vailability. Journal of the Experimental Analysis of Behavior, 1971, 16, 167-175.

DOMBER, E. A., FOWLER, H., \& WISCHNER, G. J. Shock-right facilitation: Correction training with differential $S^{D}$ availability during an enforced delay following an error. Journal of Experimental Psychology, 1971, 89, 329-334.

HEARST, E., TAUS, S. E., \& KORESKO, M. B. Generalization gradients obtained after continuous reinforcement of an operant response. Psychonomic Science, 1971, 24, 205-206.

JERNSTEDT, G. C. Joint effects of pattern of reinforcement, intertrial interval, and amount of reinforcement in the rat. Journal of 
Comparative \& Physiological Psychology, 1971, 75, 421-429.

LACHTER, G. D. Some temporal parameters of non-contingent reinforcement. Journal of the Experimental Analysis of Behavior, 1971, 16, 207-217.

LATTAL, K. A., \& MAXEY, G. C. Some effects of response independent reinforcers in multiple schedules. Journal of the Experimental Analysis of Behavior, $1971,16,225-231$.

WILKIE, D. M. Delayed reinforcement in a multiple schedule. Journal of the Experimental Analysis of Behavior, 1971, 16, 233-239.

ZIMMERMAN, D. W. Rate changes after unscheduled omission and presentation of reinforcement. Journal of the Experimental Analysis of Behavior, 1971, 15, 261-270.

\section{Partial Reinforcement}

(See Extinction for

Partial Reinforcement Effect)

BIEDERMAN, G. B. Stimulus control in partially and continuously reinforced simultaneous discrimination. Psychonomic Monograph Supplements, 1971, $4(7$, Whole No. 55$)$.

CAREY, R. J., \& FRIEDMAN, R. N. The effect of septal injury on inhibition produced by nonreinforcement and quinine. Physiology \& Behavior, 1971, 7, 123-125.

GALVANI, P. F. The effects of partial reinforcement on the acquisition and extinction of avoidance behavior in gerbils. Psychonomic Science, 1971, 24, 242-244.

MANNING, F. J., GROSS, C. G., \& COWEY, A. Partial reinforcement: Effects on visual learning after foveal prestriate and inferotemporal lesions. Physiology \& Behavior, 1971, 6, 61-64.

MILLER, J. S. Effects of a fixed-ratio schedule of brief stimulus presentations on responding maintained by concurrent DRL schedules of reinforcement. Psychonomic Science, 1971, 24, 122-124.

ROSEN, A. J., \& FREEDMAN, P. E. Goal-box experience and partial reinforcement runway effects in the rat. Journal of Comparative \& Physiological Psychology, 1971, 76, 145-151.

WALLER, T. G. The effect of consistency of reward on compound-cue discrimination learning. Psychonomic Science, 1971, 24, 230-232.

Interval Schedules

CATANIA, A. C. Reinforcement schedules: The role of responses preceding the one that produces the reinforcer. Journal of the Experimental Analysis of Behavior, $1971,15,271-287$.

CHEREK, D. R., \& HEISTAD, G. T. Fixed-interval-induced aggression. Psychonomic Science, 1971, 25, 7-8.

McMILLAN, J. C. Percentage reinforcement of fixed-ratio and variable-interval performances. Journal of the Experimental Analysis of Behavior, 1971, 15, 297-302.

NEVIN, J. A. Rates and patterns of responding with concurrent fixed-interval and variable-interval reinforcement. Journal of the Experimental Analysis of Behavior, 1971, 16, 241-247.

PADILLA, A. M. Analysis of incentive and behavioral contrast in the rat. Journal of Comparative \& Physiological Psychology, 1971, 75, 464-470.

PEAR, J. J., \& WILKIE, D. M. Contrast and induction in rats on multiple schedules. Journal of the Experimental Analysis of Behavior, $1971,15,289-296$.

SCHROT, J. F., HAWKINS, T. D., \& GITHENS, S. H. The effects of alcohol concentration on schedule-induced alcohol drinking. Psychonomic Science, 1971, 24, 201-202.

TOPPING, J. S., PICKERING, J. W., \& JACKSON, J. A. Omission training effects following VI and FI pretraining. Psychonomic Science, 1971, 24, 113-114.

\section{Ratio Schedules}

LEE, J. K., \& GOLLUB, L. R. Second-order schedules with fixed-ratio components: Variation of component size. Journal of the Experimental Analysis of Behavior, 1971, 15, 303-310.

McMILLAN, J. C. Percentage reinforcement of fixed-ratio and variable-interval performances. Journal of the Experimental Analysis of Behavior, 1971, 15, 297-302.

SHELDON, M. H. Stimulus functions in some chained fixed-ratio schedules of reinforcement. Journal of the Experimental Analysis of Behavior, 1971, 15, 311-317.

\section{Reward}

CHILLAG, D., \& MENDELSON, J. Tongue cooling: A new reward for thirsty rodents. Science, 1971, 170, 1418-1421.

D'ANDREA, T. Avoidance of timeout from response-independent reinforcement. Journal of the Experimental Analysis of Behavior, $1971,15,319-325$.
McHOSE, J. H., MAXWELL, F. R., \& McHEWITT, E. R. Effects of nonreward in $\mathrm{S}+$ and $\mathrm{S}-$ on performance in differential conditioning. Journal of Experimental Psychology, 1971, 88, 282-284.

PLISKOFF, S. S. Effects of symmetrical and asymmetrical changeover delays on concurrent performances. Journal of the Experimental Analysis of Behavior, 1971, 16, 249-256.

ROSSI, P. J. Prism-induced negative aftereffects without food-reinforced feedback in newly hatched chicks. Psychonomic Science, 1971, 24, 141-142.

WALLER, T. G. Effect of variable reward conditions on T-maze acquisition and extinction in rats. Psychological Reports, 1971, 29, 163-166.

WILKIE, D. M. Delayed reinforcement in a multiple schedule. Journal of the Experimental Analysis of Behavior, 1971, 16, 233-239.

WOOKEY, P. E., \& STRONGMAN, K. T. Emotional and instrumental effects of reward shift. Psychological Record, 1971, 21, 181-189.

COULSON, Magnitude COULSON, V. Maximization of pellet density by rats in a two-choice operant situation. Psychonomic Science, 1971, 24, 145-146.

EHRENFREUND, D. Effect of drive on successive magnitude shift in rats. Journal of Comparative \& Physiological Psychology, 1971, 76, 418-423.

FRANCHINA, J. J., \& BROWN, T. S. Reward magnitude shift effects in rats with hippocampal lesions. Journal of Comparative \& Physiological Psychology, 1971, 76, 365-370.

LIKELY, D., LITTLE, L., \& MACKINTOSH, N. J. Extinction as a function of magnitude and percentage of food or sucrose reward. Canadian Journal of Psychology, 1971, 25, 130-137.

MACKINTOSH, N. J. Reward and aftereffects of reward in the learning of goldfish. Journal of Comparative \& Physiological Psychology, 1971, 76, 225-232.

MCCLOSKEY, J. L., \& TOMBAUGH, T. N. The effects of volume of sucrose reward on resistance to extinction. Psychological Record, 1971, 21, 53-57.

\section{Differential}

BLUE, S., SHERMAN, J. G., \& PIERREL, R. Differential responding as a function of auditory 
stimulus intensity without differential reinforcement. Journal of the Experimental Analysis of Behavior, 1971, 15, 371-377.

MILLER, J. S. Effects of a fixed-ratio schedule of brief stimulus presentations on responding maintained by concurrent DRL schedules of reinforcement. Psychonomic Science, 1971, 24, 122-124.

TOPPING, J. S., PICKERING, J. W., \& JACKSON, J. A. The differential effects of omission and extinction following DRL pretraining. Psychonomic Science, 1971, 24, 137-138.

TOPPING, J. S., PICKERING, J. W., \& JACKSON, J. A. Efficiency of DRL responding as a function of response effort. Psychonomic Science, 1971, 24, 149-150.

\section{Frustration Effect}

BROOKS, C. I., \& GOLDMAN, J. A. Changes in the intensity of primary frustration during continuous nonreward. Journal of Experimental Psychology, 1971, 90, 153-155.

BRUNING, J. L., SCHMECK, R. R., \& SILVER, A. I. Frustration, competing responses, and error making. Psychonomic Science, 1971, 22, 47.48.

DALY, H. B. Evidence for frustration during discrimination learning. Journal of Experimental Psychology, 1971, 88, 205-215.

DUNLAP, W. P., HUGHES, L. F., O'BRIEN, T. J., LEWIS, J. H., \& DACHOWSKI, L. Goalbox activity as a measure of frustration in a single runway. Psychonomic Science, 1971, 23, 327-328.

PADILLA, A. M. Note on frustration theory and the partial reinforcement effect following a few acquisition trials. Psychological Reports, 1971, 28, 81-82.

PATTEN, R. L. Frustrative facilitation effects of nonzero reward magnitude reduction on goal-box activity and runway locomotion. Journal of Experimental Psychology, 1971, 90, 160-162.

PORTER, J. J., MADISON, H. L., \& SWATEK, A. J. Incentive and frustration effect of direct goal placements. Psychonomic Science, 1971, 22, 314-316.

ZIMMERMAN, D. W. Rate changes after unscheduled omission and presentation of reinforcement. Journal of the Experimental Analysis of Behavior, 1971, 15, 261-270.

\section{Probability Learning}

JONES, M. R. From probability learning to sequential processing: $\mathrm{A}$ critical review. Psychological Bulletin, 1971, 76, 153-185.
MACKINTOSH, N. J., LORD, J., \& LITTLE, L. Visual and spatial probability learning in pigeons and goldfish. Psychonomic Science, 1971, 24, 221-223.

TREICHLER, F. R. Noncorrectional probability learning and reversal by rats: Posterior decortication influence. Physiology \& Behavior, $1971,6,613-615$.

\section{EXTINCTION}

BAUM, M., JAFFE, P. G., \& LECLERC, R. The effect of a loud buzzer upon the acquisition and extinction of a simple avoidance response in rats. Canadian Journal of Psychology, 1971, 25, 24-32.

BERSH, P. J., \& KELTZ, J. R. Pavlovian reconditioning and the recovery of avoidance behavior in rats after extinction with response prevention. Journal of Comparative \& Physiological Psychology, 1971, 76, 262-266.

JAFFE, P. G., \& BAUM, M. Increased resistance-to-extinction of an avoidance response in rats following the administration of hashish resin. Psychopharmacologia (Berlin), 1971, 20, 97-102.

LIKELY, D., LITTLE, L., \& MACKINTOSH, N. J. Extinction as a function of magnitude and percentage of food or sucrose reward. Canadian Journal of Psychology, 1971, 25, 130-137.

MARX, M. H. Performance in extinction as a function of deprivation and incentive in training. Psychonomic Science, 1971, 25, 45-46.

MARX, M. H. Resistance to extinction as a function of shifts in incentive. Psychological Reports, 1971, 29, 175-179.

MYERS, D., \& SANDLER, J. Punished extinction: Facilitation or increased resistance to extinction. Psychonomic Science, 1971, 24, 111-113.

WILSON, G. T., \& DAVISON, G. C. Processes of fear reduction in systematic desensitization: Animal studies. Psychological Bulletin, 1971, 76, 1-14.

WONG, P. T. P. Coerced approach to shock, punishment of competing responses, and resistance to extinction in the rat. Journal of Comparative \& Physiological Psychology, 1971, 76, 275-281.

\section{Partial Reinforcement Effect}

BROOKS, C. I. Frustration considerations of the small-trials partial reinforcement effect: Experience with nonreward and intertrial reinforcement. Journal of Experimental Psychology, 1971, 89, 362-371.

CAPALDI, E. D. Effect of nonrewarded and partially rewarded placements on resistance to extinction in the rat. Journal of Comparative \& Physiological Psychology, 1971, 76, 483-490.

G A LBRAITH, K. Differential extinction performance to two stimuli following within-subject a cquisition. Journal of Experimental Psychology, 1971, 89, 343-350.

YOUNG, A. G., \& DAY, H. D. Effect of ECS on one-trial learning and on the partial reinforcement effect. Psychonomic Science, 1971, 24, 99-102.

Operant Conditioning

COOVER, G. D., GOLDMAN, L., \& LEVINE, S. Plasma corticosterone increases produced by extinction of operant behavior in rats. Physiology \& Behavior, 1971, 6, 261-263.

GONZALEZ, S. C., \& CARLINI, E. A. Extinction of operant responses by rats. Psychonomic Science, 1971, 24, 203-204.

SCHNELLE, J. F., WALKER, S. F., \& HURWITZ, H. M. B. Concurrent performance in septally operated rats: One and two response extinction. Physiology \& Behavior, $1971,6,649-654$.

STOLERMAN, I. P. Analysis of the acquisition and extinction of food-reinforced behaviour in rats after the administration of chlorpromazine. Psychopharmacologia (Berlin), 1971, 20, 266-279.

\section{Avoidance Conditioning}

BAUM, M. Effect of alcohol on the resistance-to-extinction of an avoidance response: Replication in mice. Physiology \& Behavior, 1971, 6, 307-309.

BAUM, M., \& HIGGINS, J. A. Extinction of an avoidance response using response prevention (flooding) in the guinea pig. Psychonomic Science, 1971, 25, 3-4.

JAMES, W. T. A methodological study of conditioning and extinction of an avoidance response via social facilitation in dogs. Journal of General Psychology, 1971, 84, 275-279.

KATZEV, $R$. The effect of the duration of the warning signal on extinguishing avoidance responses in Fischer ${ }_{3}$ rats. Psychonomic Science, 1977 1 25, 40-42.

McGOVERN, L. P., \& HAUDE, R. H. Self-punishment for responding by monkeys during extinction of discriminated avoidance: Effects of previous stimulus change reinforcement. Psychological Reports, 1971, 29, 244-246.

\section{RETENTION}

ALEXANDER, G. E., \& FUSTER, J. 
M. Neuron activity related to short-term memory. Science, 1971, 173, 652-654.

BUREŚYVÁ, O., \& BURES̀, J. The effect of prolonged cortical spreading depression on consolidation of visual engrams in rats. Psychopharmacologia (Berlin), 1971, 20, 57-65.

DAVIS, J. W., THOMAS, R. K., JR., \& ADAMS, H. E. Interactions of scopolamine and physostigmine with ECS and one trial learning. Physiology \& Behavior, 1971, 6, 219-222.

FISHBEIN, W. Disruptive effects of rapid eye movement sleep deprivation on long-term memory. Physiology \& Behavior, 1971, 6, 279-282.

FLOOD, N. B., \& OVERMIER, J. B. Effects of telencephalic and olfactory lesions on appetitive learning in goldfish. Physiology \& Behavior, 1971, 6, 35-40.

LANGFORD, A., FREEDMAN, N., \& W H T M A N, D. Further determinants of interhemispheric transfer under spreading depression. Physiology \& Behavior, 1971, 7, 65-71.

MELLO, N. K. Alcohol effects on delayed matching to sample performance by rhesus monkey. Physiology \& Behavior, 1971, 7, 77-101.

MILLER, L., DREW, W. G., \& SCHWARTZ, I. Effect of REM sleep deprivation on retention of a one-trial passive avoidance response. Perceptual \& Motor Skills, 1971, $33,118$.

PINEL, J. P. J., MALSBURY, C. W., \& CORCORAN, M. E. The incubation effect in rats: Skin resistance changes after footshock. Physiology \& Behavior, 1971, 6, 111-114.

QUARTERMAIN, D., GOLDSTEIN, M., ANAGNOSTE, B., \& RANDT, C. T. Norepinephrine biosynthesis inhibition: Effects on memory in mice. Science, 1971, 172, 498-499.

REINIS, S. Further study of the learning deficit produced by hydroxylamine. Physiology \& Behavior, 1971, 6, 31-33.

SAMUELS, I., BUTTERS, N., \& GOODGLASS, H. Visual memory deficits following cortical and limbic lesions: Effect of field of presentation. Physiology \& Behavior, 1971, 6, 447-452.

Amnesia
DAVIS, R. E., \& HOLMES, P. A.
ECS-produced retrograde amnesia
of conditioned inhibition of
respiration in cataleptic goldfish.
Physiology \& Behavior, 1971, 7,
11-14.
GIURGEA, C., LEFEVRE, D.,
L E S C R E N I E R C., \&
D A V I D - R E M A C E E, M .
Pharmacological protection against
hypoxia induced amnesia in rats.
Psychopharmacologia (Berlin),
$1971,20,160-168$.

KESNER, R. P., \& D'ANDREA, J. A. Electroconvulsive shock disrupts both information storage and retrieval. Physiology \& Behavior, 1971, 7, 73-76.

MAGNUS, J. G., \& LEE-TENG, E. The absence of residual memory consolidation following transcranial current. Physiology \& Behavior, 1971, 7, 113-115.

McDONOUGH, J. H., JR., \& KESNER, R. P. Amnesia produced by brief electrical stimulation of amygdala or dorsal hippocampus in cats. Journal of Comparative \& Physiological Psychology, 1971, 77, 171-178.

MILLER, R. R., \& SPRINGER, A. D. Temporal course of amnesia in rats after electroconvulsive shock. Physiology \& Behavior, 1971, 6, 229-233.

MISANIN, J. R.; \& HOOVER, M. Recovery rate as a determinant of the amnesic-like effect of hy pothermia. Physiology \& Behavior, 1971, 6, 689-693.

VARDARIS, R. M., \& SCHWARTZ, K. E. Retrograde amnesia for passive avoidance produced by stimulation of dorsal hippocampus. Physiology \& Behavior, 1971, 6, 131-135.

WYERS, E. J., \& DEADWYLER, S. A. Duration and nature of retrograde amnesia produced by stimulation of caudate nucleus. Physiology \& Behavior, 1971, 6, 97-103. 